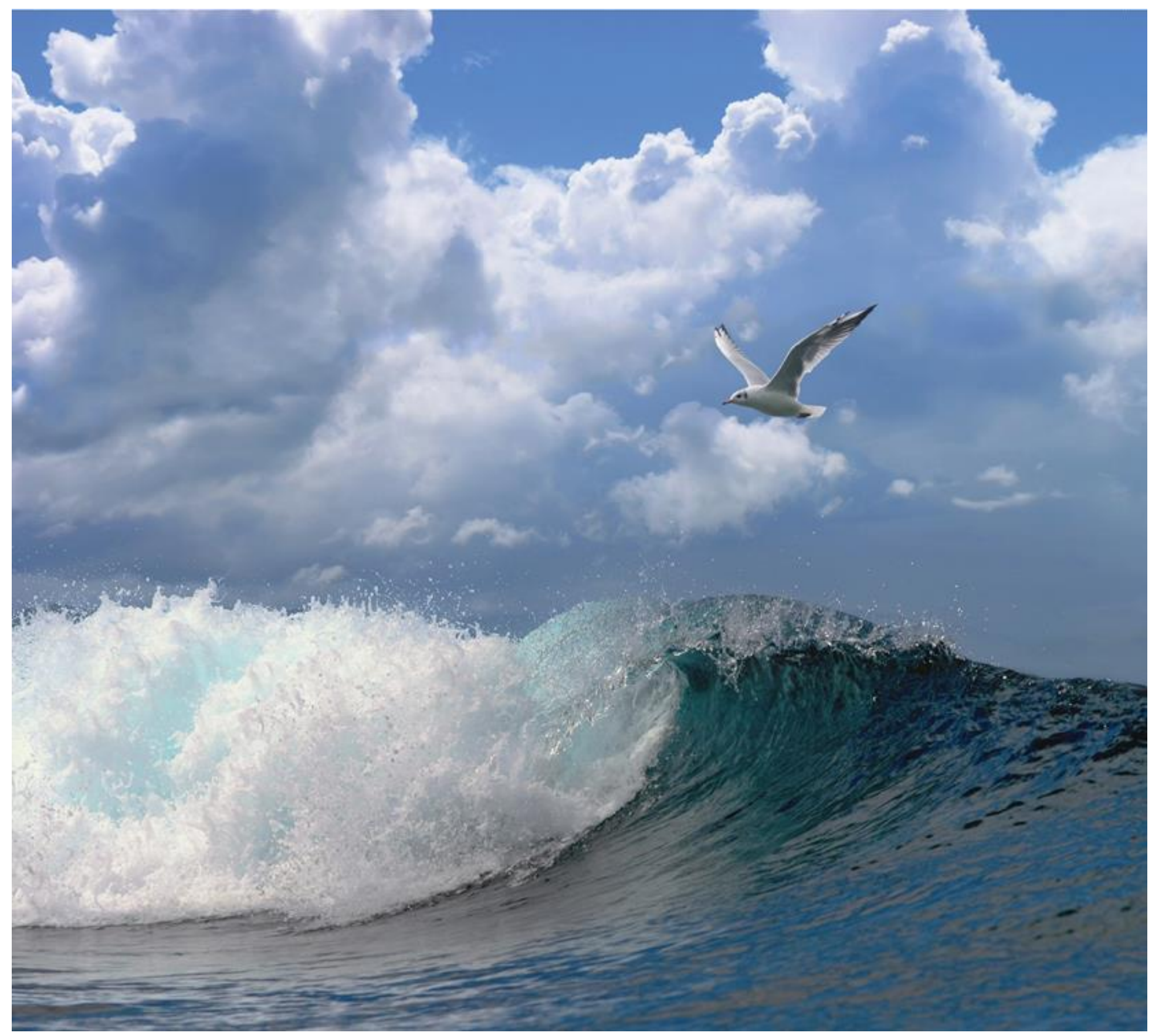

\title{
Mosselen in troebel water
}

Onderzoek naar een mogelijk effect van stof van breuksteen en staalslakken op mosselen 


\section{Mosselen in troebel water}

Onderzoek naar een mogelijk effect van stof van breuksteen en staalslakken op mosselen

Auteur(s): $\quad$ Vincent Escaravage en Pauline Kamermans

Publicatiedatum: oktober 2018

Wageningen Marine Research

Yerseke, oktober 2018

VERTROUWELIJK Nee

Wageningen Marine Research rapport C077/18 
Vincent Escaravage en Pauline Kamermans, 2018. Mosselen in troebel water; Het effect van stof van breuksteen en staalslakken op mosselen. Wageningen Marine Research Wageningen UR (University \& Research centre), Wageningen Marine Research rapport C077/18. 24 blz.

Keywords: mosselen, breuksteen, staalslakken.

Opdrachtgever: Producentenorganisatie Mosselcultuur

T.a.v.: de heer A. Risseeuw

Postbus 116,

4400 AC Yerseke

Dit rapport is gratis te downloaden van https://doi.org/10.18174/462891

Wageningen Marine Research verstrekt geen gedrukte exemplaren van rapporten.

Wageningen Marine Research Wageningen UR is ISO 9001:2008 gecertificeerd.

(C) 2016 Wageningen Marine Research Wageningen UR

Wageningen Marine Research, onderdeel van Stichting Wageningen Research KvK nr. 09098104,

IMARES BTW nr. NL 8113.83.696.B16.

Code BIC/SWIFT address: RABONL2U

IBAN code: NL 73 RABO 0373599285
De Directie van Wageningen Marine Research is niet aansprakelijk voor gevolgschade, noch voor schade welke voortvloeit uit toepassingen van de resultaten van werkzaamheden of andere gegevens verkregen van Wageningen Marine Research opdrachtgever vrijwaart Wageningen Marine Research van aanspraken van derden in verband met deze toepassing.

Dit rapport is vervaardigd op verzoek van de opdrachtgever hierboven aangegeven en is zijn eigendom. Niets uit dit rapport mag weergegeven en/of gepubliceerd worden, gefotokopieerd of op enige andere manier gebruikt worden zonder schriftelijke toestemming van de opdrachtgever. 


\section{Inhoud}

$\begin{array}{ll}\text { Samenvatting } & 4\end{array}$

$1 \quad$ Inleiding 5

1.1 Aanleiding voor het onderzoek 5

1.2 Bestaande kennis en kennisleemtes 5

1.3 Kennisvraag 7

2 Methoden $\quad 8$

2.1 Aanpak 8

2.2 Experimentele opzet 8

2.2.1 Mosselen, voedsel en toetsmateriaal 8

2.2.2 Incubatie systeem en behandelingen 8

2.2.3 Experimenteel verloop 9

$\begin{array}{ll}2.3 \text { Metingen } & 10\end{array}$

2.3.1 Zwevend stof metingen 10

$\begin{array}{lll}\text { 2.3.2 Waterkwaliteit } & 10\end{array}$

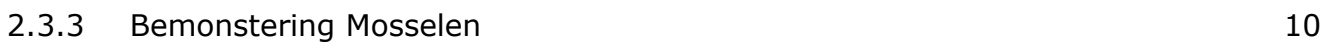

$\begin{array}{lll}2.4 & \text { Statistische analyse } & 10\end{array}$

$3 \quad$ Resultaten $\quad 11$

3.1 Waterkwaliteit tijdens de incubaties 11

3.2 Zwevende stof concentraties 12

$\begin{array}{ll}3.2 .1 \quad Z \text { wevende stof concentraties } & 12\end{array}$

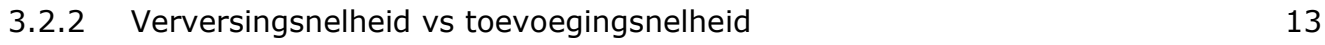

$\begin{array}{ll}\text { 3.2.3 Massa balans voor zwevende stof } & 13\end{array}$

$\begin{array}{lll}3.3 & \text { Resultaten van de histopathologische analyses } & 15\end{array}$

$\begin{array}{lll}4 & \text { Conclusies en aanbevelingen } & 17\end{array}$

$\begin{array}{lll}4.1 & \text { Histopathologische resultaten } & 17\end{array}$

$\begin{array}{ll}4.2 & \text { Experimentele omstandigheden } \\ 4.37\end{array}$

$\begin{array}{ll}4.3 & \text { Aanbevelingen } \\ & 17\end{array}$

$5 \quad$ Kwaliteitsborging $\quad 18$

$\begin{array}{lr}\text { Literatuur } & 19\end{array}$

$\begin{array}{lr}\text { Verantwoording } & 20\end{array}$

$\begin{array}{lll}\text { Bijlage } 1 & \text { Protocol Mosselsterfte experiment } & 21\end{array}$

$\begin{array}{lll}\text { Bijlage } 2 & \text { Fixeren schelpdieren voor histologisch onderzoek } & 23\end{array}$ 


\section{Samenvatting}

In het najaar van 2015 tot in de zomer van 2016 is op verschillende bodempercelen, hangcultures en MZI's in de Oosterschelde een verhoogde mosselsterfte gesignaleerd. Op basis van een histopathologisch onderzoek door Wageningen Bioveterinary Research werd geconcludeerd dat de mosselen granulocytoma's (ontstekingshaarden) hadden ontwikkeld, vermoedelijk als gevolg van een chronische blootstelling aan (toxische) stoffen vanuit de omgeving.

Ook naar aanleiding van eerdere onderzoeksresultaten werd door PO-Mossel aan WMR gevraagd om een verkennend experimenteel onderzoek uit te voeren naar het mogelijk ontstaan van granulocytoma's in mosselen bij blootstelling aan verhoogde niveaus aan zwevend stof als gevolg van de bestortingen van staalslakken en breukstenen.

Om dit te onderzoeken is een pilot experiment opgezet, waarbij het ontstaan van granulocytoma's in mosselen is onderzocht tijdens langdurige blootstelling aan breuksteen en/of staalslakken.

In het kader van dit experiment zijn groepen van mosselen ( $3 \times 10$ per behandeling) gedurende 6 weken blootgesteld aan zwevend stof afkomstig uit breuksteen en staalslakken en vergeleken met een niet blootgestelde groep. Het onderzoek is uitgevoerd binnen het meerjarige onderzoeksprogramma KOMPRO (Kennis en Onderzoek Mossel Productie).

Breuksteen: Na 13 dagen acclimatisatie onder standaard omstandigheden (gefiltreerd zeewater met voeding) en 43 dagen incubatie met bootstelling aan zwevende stof afkomstig uit breuksteen zijn granulocytoma's waargenomen in $20 \%$ van de mosselen. In de controle groep, zijn geen granulocytoma's aangetroffen na afloop van het experiment.

Staalslakken: Om logistieke redenen kon het staalslakken experiment pas 18 dagen later plaatsvinden dan het breuksteen experiment waardoor de acclimatisatieperiode is verlengd naar 31 dagen.

Vervolgens zijn deze mosselen in de behandelingsgroep 43 dagen blootgesteld aan zwevend stof afkomstig uit staalslakken. Aan het eind van de incubatie zijn granulocytoma's geconstateerd in $13 \%$ van de mosselen. Ook in de controlegroep in dit experiment is in $20 \%$ van de mosselen granulocytoma's geconstateerd.

De resultaten uit het verkennende onderzoek wijzen niet op een mogelijk verband tussen de bloostelling aan stof afkomstig van breukstenen en de ontwikkeling van granulocytoma's bij mosselen. De blootstelling aan stof uit staalslakken leidde niet tot meer granulocytoma's in de mosselen dan in de controlegroep. Mogelijk heeft de lange duur van het experiment (74 dagen) onder de standaard experimentele omstandigheden (gefiltreerd water met voeding) tot de ontwikkeling van granulocytoma's in de controlegroep geleid.

Op basis van de resultaten van deze pilot zijn de volgende aanbevelingen geformuleerd voor vervolgonderzoek:

- Gebruik van replica's bij de toepassing van de behandelingen en zo mogelijk instellen van gradiënten in zwevende stof tussen de behandelingen.

- Betere menging in de incubatiebakken om sedimentatie te beperken en daardoor de concentratie zwevend stof op peil te houden.

- Acclimatisatie periode niet langer dan 14 dagen laten duren om lang verblijf onder experimentele omstandigheden te voorkomen.

- Onderzoek doen naar de ontwikkeling van granulocytoma's in natuurlijke situatie en als functie van het verblijf in experimentele omstandigheden. 


\section{$1 \quad$ Inleiding}

\subsection{Aanleiding voor het onderzoek}

In het najaar van 2015 tot in de zomer van 2016 is op verschillende bodempercelen, maar ook in hangcultures en MZI's in de Oosterschelde een verhoogde mosselsterfte gesignaleerd (tot 40\%) terwijl het vleesgehalte goed was (memo Gert Jan van Veen dd. 4 augustus 2016). De sterfte vond plaats in alle grootte- en herkomstklassen. De getroffen individuen waren gekenmerkt door een glazig uiterlijk (Figuur 1).

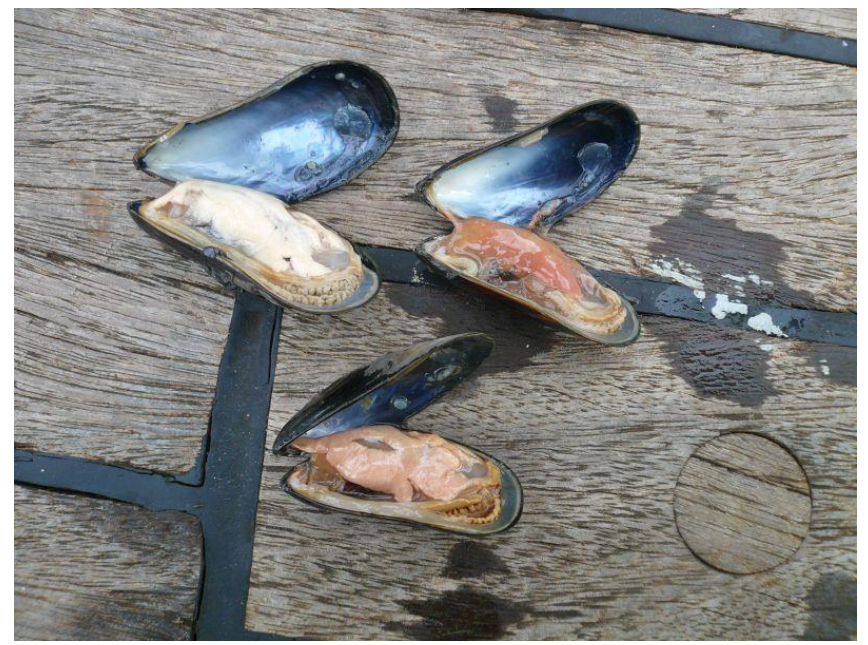

Figuur 1.- Goed vleesgehalte en glazig uiterlijk van mosselen van een perceel met mosselsterfte Bron: Pauline Kamermans WMR.

\subsection{Bestaande kennis en kennisleemtes}

Als mogelijke oorzaken voor massale sterfte van mosselen op de percelen wijst Wijsman (2016), naast vraat door predatoren en het wegspoelen als gevolg van storm, naar zuurstofloosheid, parasieten en ziektes, voedselopname en gifstoffen.

Om aanvullende informatie m.b.t. de mosselsterfte in het najaar van 2015 tot in de zomer van 2016 achter te halen zijn mosselmonsters genomen. Pp 5 augustus 2016 zijn monsters van de bodempercelen Hammen 105, OSWD 180 en OSWD 72 aangeleverd aan WBR (Wageningen Bioveterinary Research, voorheen CVI) voor analyse (Figuur 2). 


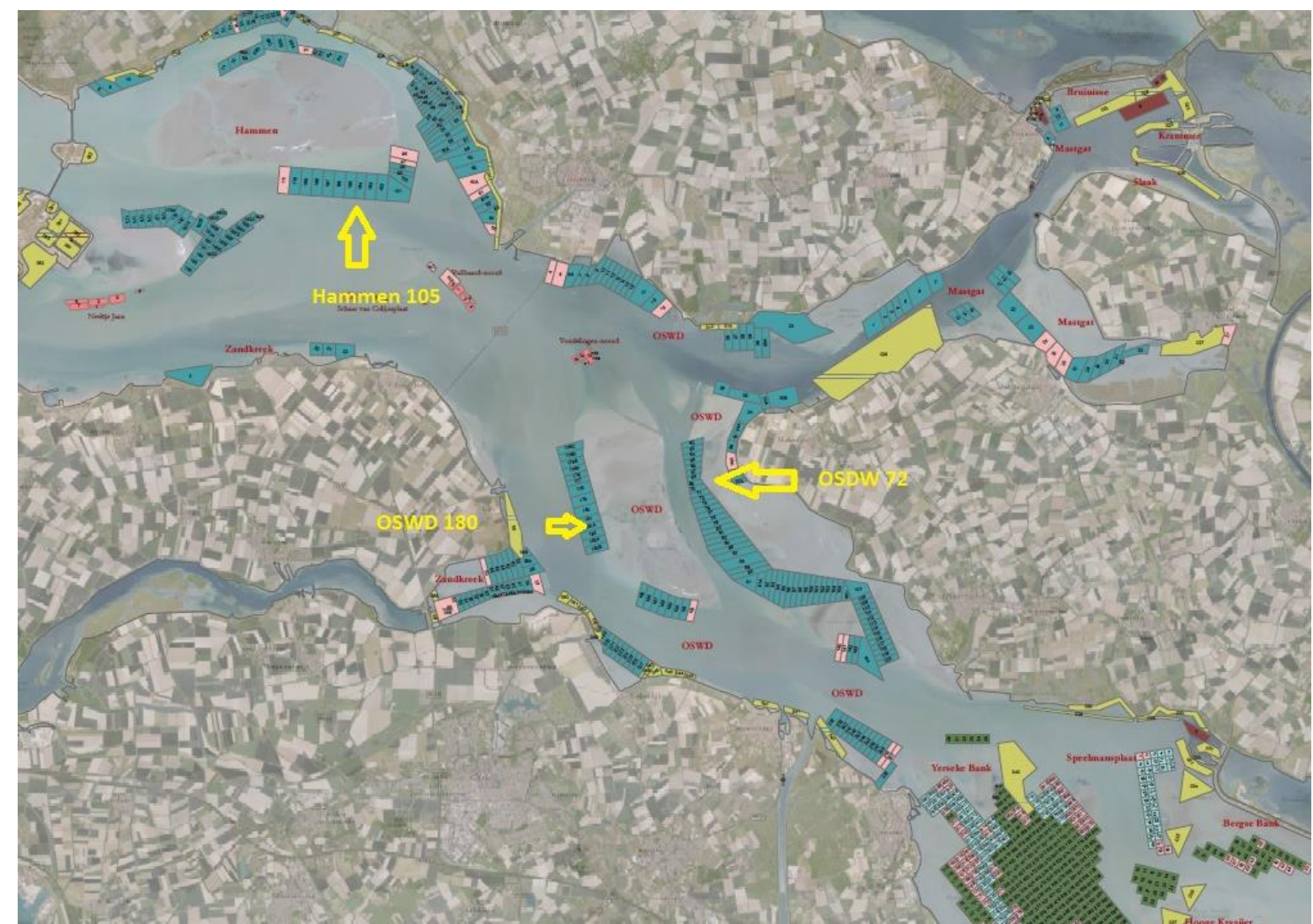

Figuur 2. Locaties mosselmonsters in de Oosterschelde. Bron: Gert Jan van Veen RvO.

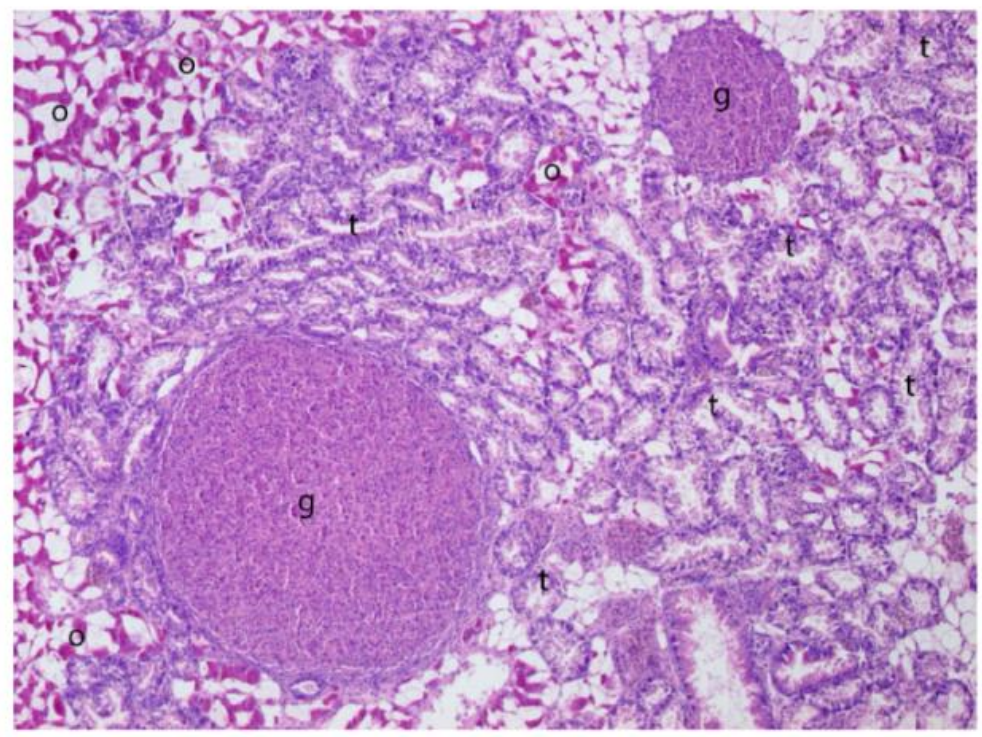

Figuur 3.- Histologische coupe van mosselweefsel met granulocytoma's ( $\mathrm{g}$ ) naast het verteringsstelsel $(t)$ en daaromheen cellen voor opslag van energie reserves (o). Bron: WBR.

Er werd geconcludeerd door WBR dat de mosselen geen voedsel tekort hadden geleden en dat geen ziektes en/of parasieten verantwoordelijk waren voor de sterfte. Er waren wel veel granulocytoma's (ontstekingshaarden, Figuur ) waargenomen in de weefsels van de mosselen. Granulocytoma's worden vaak in aquatische organismen gevonden die leven in stressvolle omgevingen zoals estuaria en worden onder andere geassocieerd met blootstelling aan metalen of organische vervuilende stoffen (Sunila, 1986; Auffret, 1988; Bignell et al 2011). De aanwezigheid van granulocutoma's kan dus duiden op chronische blootstelling aan (toxische) stoffen vanuit de omgeving.

Als mogelijke bronnen van toxische stoffen in de Oosterschelde werd eerder gedacht aan de munitiestort bij Zierikzee en aan de staalslakken en breukstenen gebruikt voor de dijkverzwaringen. Op basis van de bevindingen in Jansen et al. (2015), Wijsman et al. (2015) en Foekema et al. (2016) lijkt het niet waarschijnlijk dat de samenstellingen en hoeveelheden aan toxische stoffen die uit die bronnen uitlogen een mogelijke oorzaak kunnen zijn voor de huidige mosselsterfte. 
In Smaal (2015) is ingegaan op de vraag in hoeverre de vertroebeling van het water als gevolg van vooroeverbestorting met zeegrind in 2014 verantwoordelijk kon zijn voor de waargenomen verhoogde mosselsterfte in 2014 op nabijgelegen percelen.

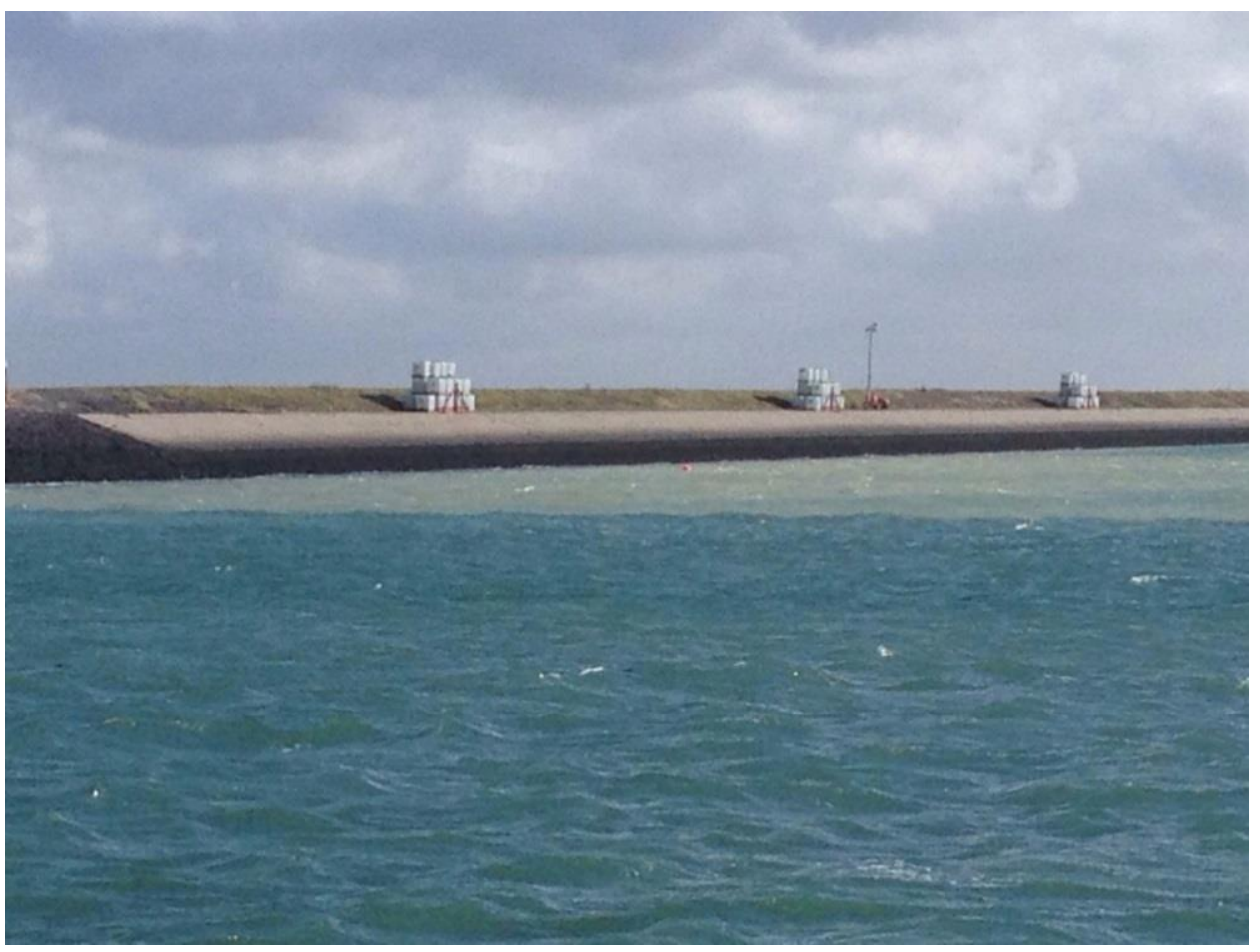

Figuur 4.- Grindstorten en vertroebeling van het water nabij Schelphoek (detail) uit Smaal (2015).

Door gebrek aan andere verklaringen kon toen niet worden uitgesloten dat de verhoogde niveaus aan zwevend stof als gevolg van de bestorting verantwoordelijk konden zijn voor de mosselsterfte. Er zijn visuele waarnemingen (figuur 4) van verhoogde concentraties zwevend stof tijdens het storten van het grind, maar er zijn geen metingen uitgevoerd. Ook zijn er geen mosselen verzameld voor analyse op de aanwezigheid van granulocytoma's.

Net als grind bevatten breukstenen resten van klei/slibachtig materiaal waardoor het water ook troebel raakt na een bestorting.

\subsection{Kennisvraag}

Als vervolg op de onderzoeksresultaten van Smaal (2015) en Foekema et al. (2016) is door PO-Mossel gevraagd een verkennend experimenteel onderzoek uit te voeren naar het ontstaan van granulocytoma's in mosselen tijdens blootstelling aan verhoogde niveaus aan zwevend stof zoals het geval is tijdens de bestortingen van staalslakken en breukstenen. Het onderzoek is uitgevoerd binnen het meerjarige onderzoeksprogramma KOMPRO (Kennis en Onderzoek Mossel Productie).

De werkhypothese van het onderzoek luidt als volgt: Het vrijkomen van materiaal (zwevend stof van breukstenen of staalslakken) afkomstig van bestortingen (dijken, ontgrondingskuilen kering) zou mogelijk chronische stress in mosselen kunnen veroorzaken dat zich uit in de ontwikkeling van granulocytoma's.

Door de kleinschaligheid waarvoor gekozen werd bij de opdrachtverlening moet het huidige experiment worden gezien als een pilot, met als doel te onderzoeken of er überhaupt granulocytoma's ontstaan en kennis en ervaring op te doen met de experimentele opzet voor eventuele vervolgexperimenten. 


\section{$2 \quad$ Methoden}

Ten behoeve van de traceerbaarheid en reproduceerbaarheid van het uitgevoerde experiment is het gebruikte protocol toegevoegd in Bijlage 1 van deze rapportage.

\section{$2.1 \quad$ Aanpak}

In het kader van dit experiment zijn groepen van mosselen ( $3 \times 10$ per behandeling) gedurende 6 weken blootgesteld aan zwevend stof afkomstig uit breuksteen en staalslakken en vergeleken met een niet blootgestelde groep. Een periode van 6 weken wordt gezien als voldoende lang voor het ontstaan van granulocytoma's (mondelinge mededeling Marc Engelsma Wageningen Veterinairy Research). De mosselen zijn bijgevoerd met een gestandaardiseerd "shellfish diet" om er voor te zorgen dat de mosselen voldoende voedsel krijgen en dat er geen schommeling in de voedselbeschikbaarheid optreedt tijdens het experiment.

De mosselen zijn afkomstig uit de Waddenzee, waar tot op heden geen verhoogde percentages aan granulocytoma's zijn geobserveerd. Voorafgaand aan het experiment en na 6 weken is een monster van de mosselen genomen van de verschillende behandelingsgroepen (Controle, Staalslakken, Breukstenen) en door WBR geanalyseerd op de aanwezigheid van granulocytoma's.

\subsection{Experimentele opzet}

\subsubsection{Mosselen, voedsel en toetsmateriaal}

De mosselen gebruikt voor dit experiment zijn consumptie mosselen (ca 2 jaar) opgevist op mossel perceel Balgen 20 in de Waddenzee op 15 november 2017 en opgehaald bij de kweker in Yerseke op 16 november 2017.

Direct na ontvangst werden de mosselen geplaatst in het incubatie system (zie 2.2.2) waar ze gevoed werden met Shellfisch Diet $1800^{\circledR}$, een voedingsmiddel ontwikkeld en verhandeld door Reed Mariculture Inc. (http://reedmariculture.com). SD 1800 bestaat uit een mengsel van microalgen (Isochrysis, Pavlova, Tetraselmis, Chaetoceros calcitrans, Thalassiosira weissflogii en Thalassiosira pseudonana). Deze samenstelling is specifiek ontwikkeld voor de voeding van gekweekte schelpdieren zoals oesters, mosselen en sint jakobsschelpen. De voedselsuspensie is aangeboden aan de mosselen met een debiet van 3,3 I per 24 u waarmee de chlorofyl concentratie van incubatiesystemen minimaal $4 \mu \mathrm{g} . \mathrm{I}^{-1}$ was. Dit is een concentratie waarbij de mosselen geen voedsel tekort ervaren maar nog steeds actief water blijven filtreren (Wijsman et al., 2012).

Het in stand houden van een actieve filtratie zorgt voor een effectieve blootstelling van de mosselen aan de zwevende stof afkomstig uit breukstenen en staalslakken zoals gebruikt i.h.k.v. de vooroeververdediging. De breukstenen, bekend als "Ardenner Breuksteen" hebben afmetingen van 5 tot $30 \mathrm{~cm}$ en zijn afkomstig van Pekaar bestratingsmaterialen B.V. De staalslakken, bekend als "LD staalslakken", hebben afmetingen van 45 tot $180 \mathrm{~mm}$ en zijn afkomstig van De Hoop Bouwgrondstoffen.

\subsubsection{Incubatie systeem en behandelingen}

Een schema van de experimentele opzet is weergegeven in Figuur 5. Aan het begin van het experiment zijn de incubatiebakken gevuld met gefiltreerd zeewater en aangesloten via een peristaltische pomp aan een 20 I voedingsbak gevuld met een oplossing van SD 1800. De voedingsbak is gekoeld (koelbad $1^{\circ} \mathrm{C}$ ) en continu geroerd (pomp) om het voedsel in goede staat en in suspensie te houden. Drie maal per week is een nieuwe voorraad algen aangemaakt.

De mosselen verbleven eerst minimaal een week in de incubatiebakken om te acclimatiseren onder de experimentele omstandigheden (temperatuur, gefiltreerd zeewater + voeding) waarna gestart is met de experimentele behandelingen. Widdows \& Bayne (1971) hebben een acclimatie periode van minimaal een week vastgesteld voor mosselen. De experimentele behandelingen bestaan uit het toevoegen van zwevende stof afkomstig uit breukstenen (BS) of staalslakken (SS) aan de incubatiebakken en een controle zonder breuksteen of staalslakken (CTRL, controle).

Voor de toepassing van de behandelingen zijn de incubatiebakken aangesloten via een peristaltische pomp aan 60 I cementkuipen (voorraadbakken) gevuld met gefiltreerd zeewater. Het water werd 


\section{toegevoegd aan de incubatiebakken met een debiet van 13,5 I per 24u oftewel een}

vervangingssnelheid van $54 \%$ per dag. Als behandelingen zijn breukstenen (BS) en staalslakken (SS) geplaatst in de voorraadbakken à $125 \mathrm{~g}$ per liter. In de CTRL behandeling werd alleen gefiltreerd zeewater aan de incubatiebak toegevoegd. Alle voorraadbakken waren voorzien van twee dompelpompen zodanig geplaatst om stromingen in tegenovergestelde richtingen te genereren. Door middel van een afwisseling tussen aan en uit met behulp van een tijdklok zorgt die configuratie ervoor dat zo veel mogelijk stof in suspensie blijft.

De incubatiebakken zijn wekelijks leeg en schoon gemaakt, aangevuld met gefiltreerd zeewater en weer aangesloten aan de pomp voor toevoeging van voedsel suspensie.

De mosselen zijn geplaatst in netjes met 10 individuen per netje en drie netjes per behandeling

(Fout! Verwijzingsbron niet gevonden.). De netjes hingen in cementkuipen (incubatiebakken) van 25 I voorzien van een luchttoevoer en een overloop.

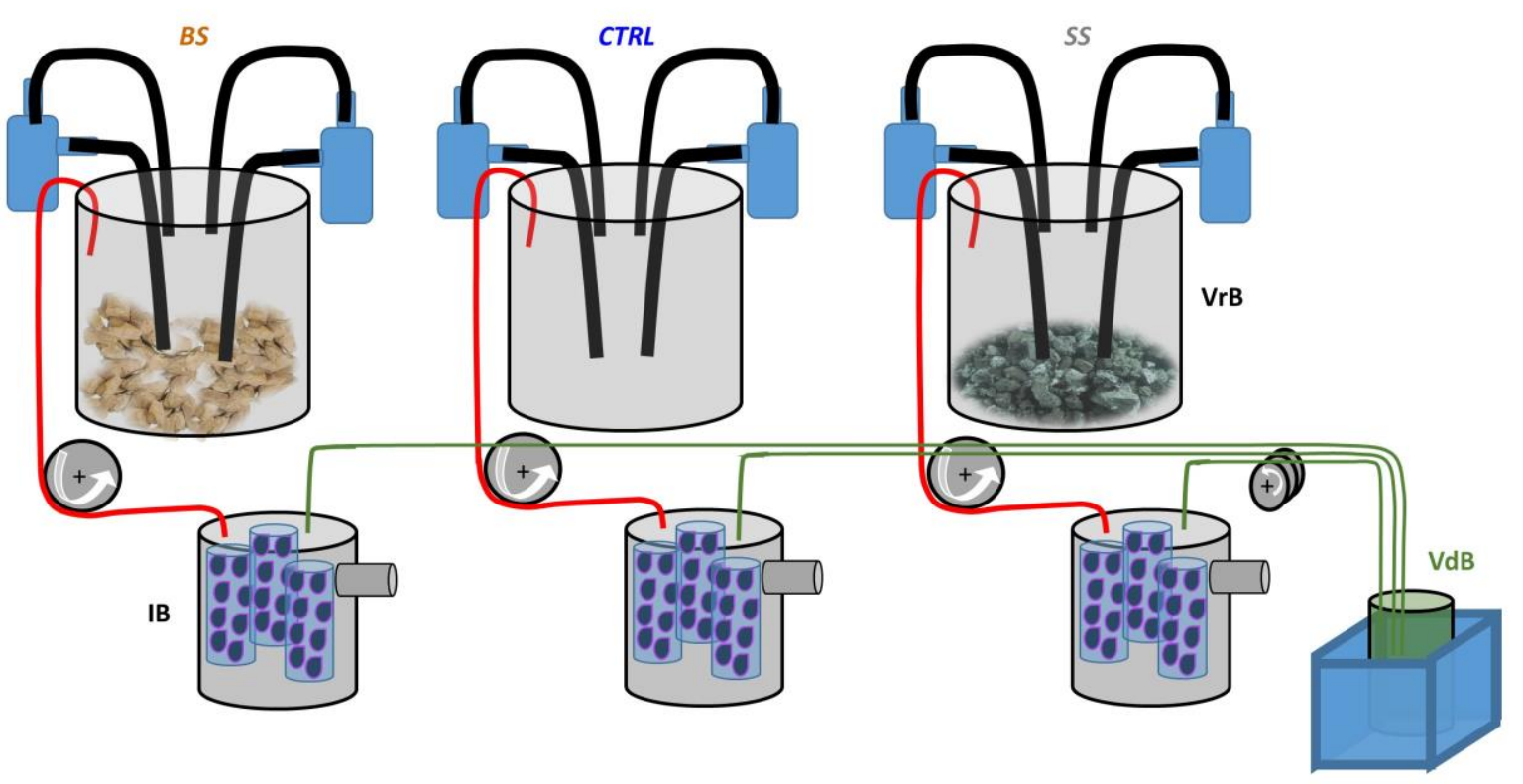

Figuur 5.-Experimentele opzet voor de blootstelling van mosselen aan zwevende stof afkomstig uit breukstenen (BS) en staalslakken (SS). IB: Incubatiebakken met elk 3 netjes met 10 mosselen, VdB: Voedingsbak in koelbad van $1^{\circ} \mathrm{C}$ en aansluitingen via peristaltische pomp met de incubatiebakken. VrB: Voorraadbakken met wel (BS, SS) of geen (CTRL) toevoeging van breukstenen of staalslakken en aansluitingen via peristaltische pomp met de incubatiebakken.

\subsubsection{Experimenteel verloop}

Het incubatie-experiment met de breuksteen is op 29 november 2017 gestart. Door de late levering van de staalslakken is het incubatie-experiment met de staalslakken later gestart (18 december 2018).

Als gevolg van deze vertraging, zijn de mosselen gebruikt voor het staalslakken experiment 32 dagen in het incubatie systeem gehouden voorafgaand aan het begin van de blootstelling. Voor het breukstenen experiment was de acclimatisatieperiode slechts 13 dagen.

In beide experimenten werd de incubatie zoals gepland na 6 weken gestopt (Breuksteen=11 januari 2018, Staalslakken=29 januari 2018) om de mosselen te laten analyseren door de WBR op de aanwezigheid van granulocytoma's. Tabel 1 geeft een overzicht van de monstername momenten. 
Tabel 1. Grootte van de mosselmonsters per behandeling (Controle, Breuksteen, Staalslakken) en tijdstip (T0 = start van de behandeling, T6= na 6 weken).

\begin{tabular}{|c|c|c|}
\hline Datum & Mosselmonsters & Aantal mosselen \\
\hline $16-11-17$ & T0 Controle voor Breuksteen & 30 \\
\hline $11-01-18$ & T6 Controle voor Breuksteen & 10 \\
\hline $11-01-18$ & T6 Breuksteen & 30 \\
\hline $18-12-17$ & T0 Controle voor Staalslakken & 10 \\
\hline $29-01-18$ & T6 Controle voor Staalslakken & 10 \\
\hline $29-01-18$ & T6 Staalslakken & 30 \\
\hline
\end{tabular}

\subsection{Metingen}

\subsubsection{Zwevend stof metingen}

De concentratie zwevend stof in het water is één maal per week gemeten d.m.v. wegingen na het filtreren van een bekende hoeveelheid water (100-1000 $\mathrm{ml}$ ) op een gewogen filter, het drogen ervan bij $70{ }^{\circ} \mathrm{C}$ en het opnieuw wegen. Het verschil (voor en na) in gewicht levert de concentratie aan zwevend stof op (ZS, mg/l).

\subsubsection{Waterkwaliteit}

Fysicochemische metingen in het water van de incubatiebakken zijn wekelijks uitgevoerd ter controle van de waterkwaliteit door de tijd en/of tussen de behandelingen. Standaard waterparameters zoals temperatuur, zoutgehalte, $\mathrm{pH}$ en zuurstof zijn gemeten met behulp van elektronische sensoren ( $\mathrm{Ph}$, temperatuur, zuurstof: $\mathrm{HACH}^{\mathrm{TM}} \mathrm{HQ} 40 \mathrm{~d}$ multimeter; zoutgehalte: $\mathrm{HACH}^{\mathrm{TM}} \mathrm{HQ14D}$ Digitale geleidbaarheidsmeter).

Voor de bepaling van $\mathrm{NH}_{4}$ als indicator voor verstoringen van de stikstofhuishouding is gebruik gemaakt van de visuele kleurenkit Ammoniumtest (MColortest ${ }^{\mathrm{TM}}$, Merck ${ }^{\mathrm{TM}}$ ) met een minimale detectiewaarde van $0,5 \mathrm{mg} / \mathrm{l}$.

\subsubsection{Bemonstering Mosselen}

Voorafgaand aan het experiment en na afloop zijn mosselen bemonsterd van de verschillende behandelingen om door WBR geanalyseerd te worden op de aanwezigheid van granulocytoma's. Voorafgaand aan het versturen naar de WBR zijn de monsters gefixeerd m.b.v. het Davidson fixatief volgens de geldende procedure (Bijlage 2).

\subsection{Statistische analyse}

Hoewel de experimentele opzet vooral gezien moet worden als een pilot zijn de resultaten voor de breuksteen statistisch geanalyseerd. Hierbij is het verschil tussen de initiële waarden van granulocytoma's in mosselen en de waarden in de mosselen na de incubatie met breukstenen getest met een t-test. 


\section{Resultaten}

\subsection{Waterkwaliteit tijdens de incubaties}

Tijdens de experimenten tonen alle fysicochemische variabelen $\left(\mathrm{pH}, \mathrm{O}_{2}, \mathrm{~S} \%\right.$, $\left.\mathrm{T}^{\circ} \mathrm{C}\right)$ zeer vergelijkbare waarden in de Controle en de Incubatie-bakken. In alle bakken zijn zeer afwijkende waarden (hoge $\mathrm{pH}, \mathrm{O}_{2}$ en lage $\mathrm{S} \%$, $\mathrm{T}^{\circ} \mathrm{C}$ ) waargenomen op 20 december waar de meting vlak na het verversen van de incubatiebakken uitgevoerd werd in plaats van ervoor zoals voorgeschreven in het protocol (Figuur 2). Alle metingen van $\mathrm{NH}_{4}$ zijn onder kritische waarden voor mosselen (Tabel 2; protocol in Bijlage 1).
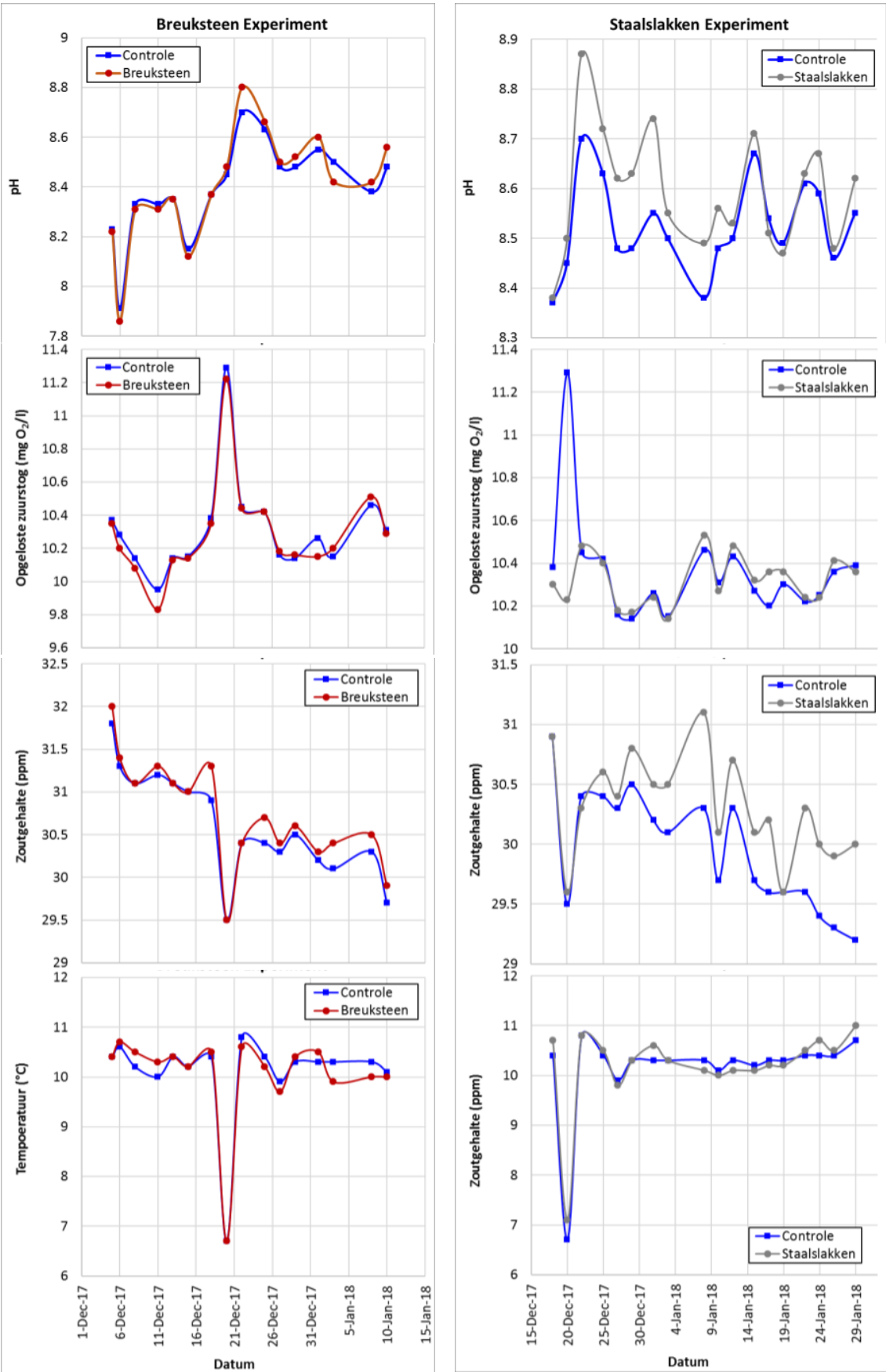

Figuur 2.-Waarden voor de waterkwaliteit variabelen $(\mathrm{pH}$, opgeloste Zuurstof, Zoutgehalte en Temperatuur) 3 keer per week bepaald in de incubatiebakken tijdens de Breuksteen en Staalslakken experimenten.

Het water in de incubatiebak met staalslakken werd overigens gekenmerkt door hogere waarden van $\mathrm{pH}$ en zoutgehalte dan het water in de controle bak. Hogere waarden van $\mathrm{pH}$ in aanwezigheid van staalslakken is ook gerapporteerd door Foekema et al. (2016) en in relatie gebracht met de uitloging van basische stoffen uit de staalslakken. De uitloging van ionen uit de staalslakken kan van invloed 
zijn op de geleidbaarheidsmeting bij de bepaling van het zoutgehalte van water dat in contact is met staalslakken.

Tabel 2. Waarden voor opgelost stikstof dat wekelijks is bepaald in de incubatiebakken tijdens de Breuksteen en Staalslakken experimenten.

\begin{tabular}{|c|c|c|c|c|c|c|}
\hline & Staalslakken & & \multicolumn{2}{l|}{ Breuksteen } & \multicolumn{2}{l|}{ Controle } \\
\hline datum & $\mathrm{NH} 4$ & $\mathrm{NO2}$ & $\mathrm{NH} 4$ & $\mathrm{NO2}$ & $\mathrm{NH} 4$ & $\mathrm{NO} 2$ \\
\hline 8/dec & & & 0 & & 0 & \\
\hline 11/dec & & & 0 & & 0 & \\
\hline 18/dec & 0 & & 0 & & 0 & \\
\hline $27 /$ dec & 0 & & 0 & & 0 & \\
\hline 8/jan & 0 & 0,5 & 0 & 0,5 & 0 & 0,5 \\
\hline 15/jan & 0 & 0,2 & & & 0 & 0,3 \\
\hline 22/jan & 0 & 0,1 & & & 0 & 0,1 \\
\hline 29/jan & 0 & 0,1 & & & 0 & 0,1 \\
\hline
\end{tabular}

-> De fysicochemische variabelen $\left(\mathrm{pH}, \mathrm{O}_{2}, \mathrm{~S} \%\right.$, $\left.\mathrm{T}^{\circ} \mathrm{C}\right)$ laten weinig afwijking zien tussen de experiment behandelingen en de controle. Alleen de verhoogde zuurstofconcentratie op 20 december die is veroorzaakt door het schoonmaken van de incubatiebakken is niet opgetreden in de incubatiebak met staalslakken.

->Alle metingen van $\mathrm{NH}_{4}$ zijn onder kritische waarden voor mosselen.

\subsection{Zwevende stof concentraties}

\subsubsection{Zwevende stof concentraties}

Tijdens de incubaties bleek het niet eenvoudig om de concentraties aan zwevend stof in de incubatiebakken op peil te houden vanwege sedimentatie in de bakken. In de incubatiebakken zijn daarom vanaf 19 december mechanische roerders aangebracht om sedimentatie tegen te gaan.

A

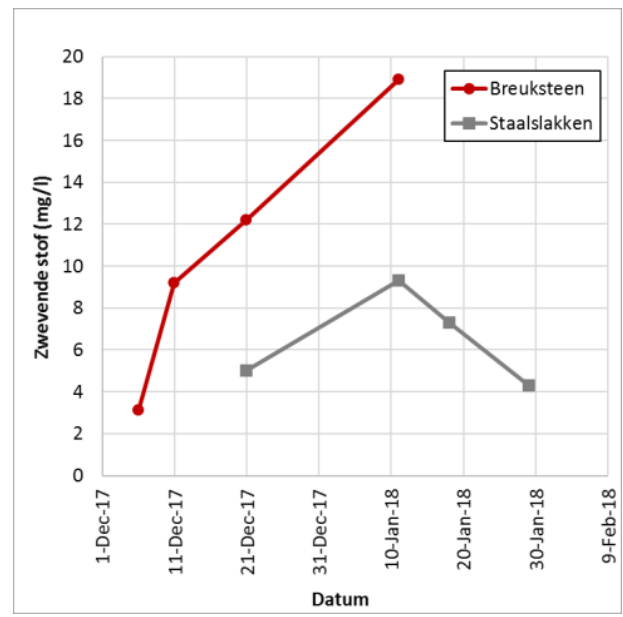

B

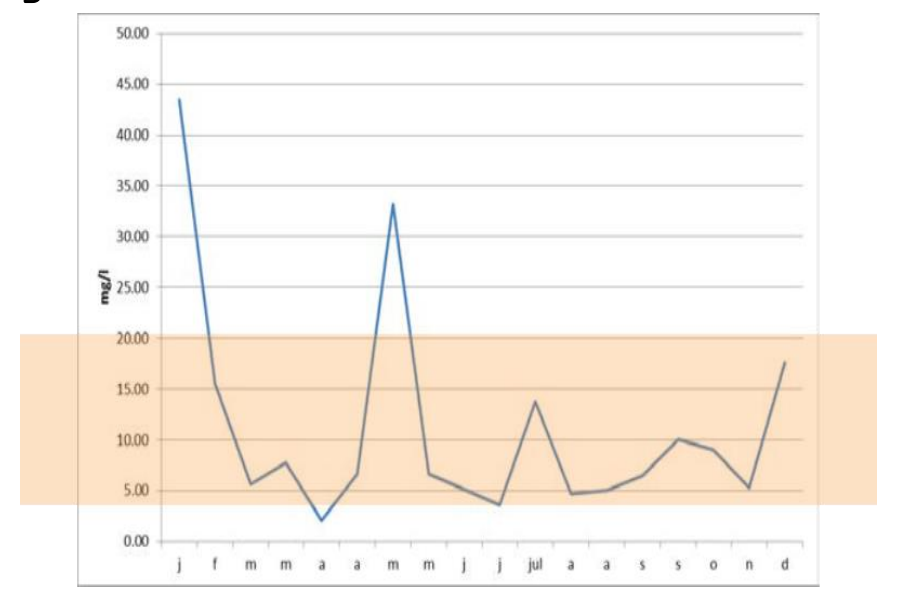

Figuur 6.-A: Concentraties aan zwevende stof gemeten in de Breuksteen en Staalslakken incubatiebakken tijdens het experiment. B: Concentraties aan zwevende stof gemeten in 2014 meetpunt Wissenkerke (data RWS) uit Smaal (2015) met daarop getekend de bandbreedte aan ZS waarden waargenomen tijdens het huidige experiment.

De concentratie aan zwevende stof zijn ca 2,5 keer hoger in de Breuksteen- dan in het Staalslakkenexperiment. Het natuurlijke verloop van de achtergrond concentraties aan zwevende stof in de Oosterschelde is gekenmerkt door grote variaties. Uit de RWS data van de locatie Wissenkerke in 2014 bijvoorbeeld blijkt de concentratie zwevend stof te variëren tussen van 2,5 mg/l tot meer dan 40 
mg/l (Figuur B uit Smaal (2015)); voor ca de helft van de tijd liggen de ZS gehaltes in het veld wel lager dan $10 \mathrm{mg} / \mathrm{l}$.

-> Met gemiddelde waarden van 10,9 en 6,5 mg/l waargenomen in de BS- en SS-incubatiebakken zijn de zwevende stof gehaltes in het huidige experiment goed vergelijkbaar met de gemiddelde achtergrond waarde van $8 \mathrm{mg} / \mathrm{l}$ voor de Oosterschelde (Smaal et al., 2015).

$->$ Het zwevende stof gehalte in de behandeling BS is bijna $70 \%$ hoger dan in SS.

\subsubsection{Verversingsnelheid vs toevoegingsnelheid}

In een eerder uitgevoerde mesocosm studie naar het effect van staalslakken, breukstenen en grind op mosselen (Foekema et al., 2016) is gebruik gemaakt van twee verversingssnelheden: 430 volume $\%$ per dag, beschouwd o.b.v. modelberekeningen als representatief de Oosterschelde en 10 volume $\%$ per dag als niet representatief "worst case" scenario om zo mogelijk negatieve effecten te accentueren. In die studie ging het om de uitlogging van staalslakken en breukstenen waar de verversingsnelheid de accumulatie van die opgeloste stoffen tegengaat.

->In het huidige experiment zorgt de continu toevoer van suspensie uit de voorraadbakken voor het op peil houden van ZS concentraties in de incubatiebakken. Zonder die toevoer zou de concentratie vrij snel afnemen door het neerslaan op de bodem van de incubatiebakken door spontane flocculatie en/of actieve incorporatie in pseudofeces door mosselen.

\subsubsection{Massa balans voor zwevende stof}

Zwevende stof speelt een centrale rol in het huidige experiment waardoor het relevant is om de dynamische processen die verantwoordelijk zijn voor de waargenomen concentraties goed in kaart te brengen.

Op basis van het huidige experiment is getracht om een massa balans voor zwevende stof op te stellen. Daarvoor is de concentratie aan zwevende stof in de incubatiebakken berekend d.m.v. een eenvoudig flux model (MS Excel ${ }^{\mathrm{TM}}$ ) op basis van de concentratie in de voorraadbak en het debiet van toe- en afvoer in afwezigheid van sedimentatie. $\mathrm{Ci}_{1}=\mathrm{Ci}_{0}+\left((\mathrm{Dv} * \mathrm{Cv})-((\mathrm{Ci} /(\mathrm{Dv}+\mathrm{Cv}) * \mathrm{Dv}))\right.$, waarbij $\mathrm{Ci}_{1}$ de concentratie aan zwevende stof in $\mathrm{mg} / \mathrm{l}$ in de incubatiebak op tijdstip 1 is, $\mathrm{Ci}_{0}$ de concentratie aan zwevende stof in $\mathrm{mg} / \mathrm{l}$ in de incubatiebak op tijdstip 0 is, Dv het debiet van de pomp in $\mathrm{l} / \mathrm{h}$ van voorraadbak naar incubatiebak, Cv de concentratie aan zwevende stof in de voorraadbak in $\mathrm{mg} / \mathrm{l}$. Voor deze berekening is gebruik gemaakt van de gegevens van 6 en 11 december 2017 met concentraties aan zwevend stof afkomstig van breuksteen in de voorraadbak van $173 \mathrm{mg} / \mathrm{l}$ ( 6 december) en $214 \mathrm{mg} / \mathrm{l}$ ( 11 december) toegevoegd aan de $25 \mathrm{I}$ incubatiebak met een debiet van 13,5 $\mathrm{I} / \mathrm{d}$. De concentraties in de incubatiebak zijn berekend met tijdsstappen van een uur en vergeleken met de waargenomen concentraties van respectievelijk $3,1 \mathrm{mg} / \mathrm{l}$ bij aanvang op 6 december en 9,2 mg/I na 120 uur 11 december (Figuur 3 links). 

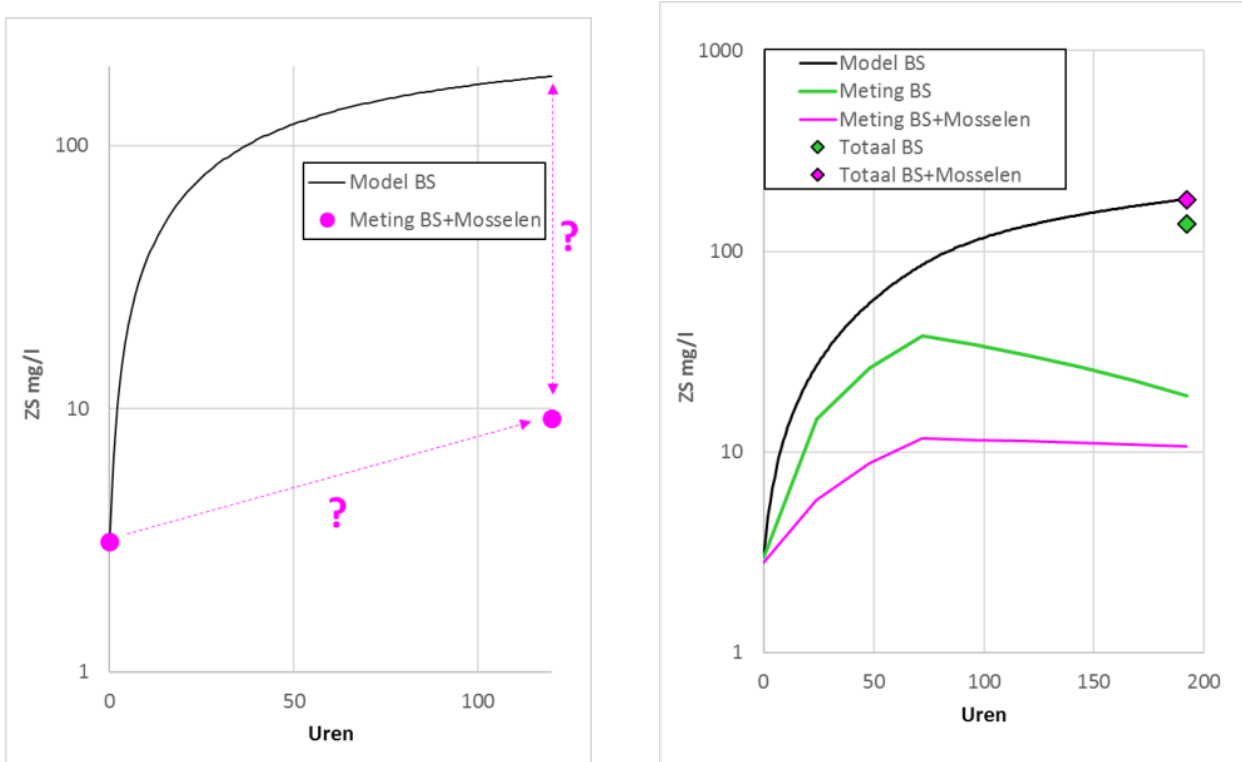

Figuur 3.-A: Gemeten waarden van zwevende stof concentraties in de incubatie bak tijdens het breuksteen (BS) experiment op 6 december (0 uur) en 11 december (120 uur) 2017 en model berekening zonder sedimentatie over dezelfde periode (zie uitleg m.b.t. de pijlen in tekst). B: resultaten van aanvullend experiment naar zwevende stof dynamiek (3-11 april 2018) met gemeten waarden in incubatie bakken met en zonder mosselen en totale hoeveelheid materiaal in die bakken verzameld na afloop van het experiment te vergelijken met de modelberekeningen in afwezigheid van sedimentatie.

Volgens het model waar geen sedimentatie plaats vindt nemen de concentraties aan zwevende stof in de incubatiebak gestaag toe tijdens de eerste 48 uren en vlakt die trend vervolgens af tot een concentratie van ca $183 \mathrm{mg} / \mathrm{l}$ na 120 uur (Figuur 37 links). Vergeleken met de werkelijke waarneming van $9 \mathrm{mg} / \mathrm{l}$ is het zeer waarschijnlijk dat het leeuwendeel van het toegevoegde materiaal in de incubatiebak bezinkt. Vragen bestaan nog wel over i. -de ontwikkeling van de zwevende stof concentratie tijdens de incubatieperiode, ii.-de fractie van het materiaal die in de bak bezinkt/afgevoerd wordt en de rol van de mosselen in deze processen (Zie vraagtekens in Figuur 3 links).

Met als doel deze processen beter in kaart te brengen is een aanvullende proef uitgevoerd in twee incubatiebakken: een zonder (BS) en een met mosselen (BS+Mosselen) aangesloten aan een voorraadbak gevuld met breukstenen. Dagelijks is de concentratie aan zwevende stof gemeten in het water uit het voorraadbak en in de incubatiebakken. Na een week incubatie (192 u) is de hoeveelheid stof neergeslagen in de incubatiebakken gemeten om de massabalans te kunnen sluiten en om de situaties met en zonder mosselen te kunnen vergelijken.

Uit de modelberekeningen blijkt dat na 192 uur incubatie de concentratie zwevend stof $182 \mathrm{mg} / \mathrm{l}$ is in afwezigheid van sedimentatie (Figuur 7 rechts). Na drie dagen van toename zwevende stof concentratie tot 12 in de bak met mosselen en $38 \mathrm{mg} / \mathrm{l}$ in de bak zonder mosselen blijft de concentratie vervolgens rondom $11 \mathrm{mg} / \mathrm{l}$ in de bak met mosselen en neemt af van 38 tot $19 \mathrm{mg} / \mathrm{l}$ in de laatste vijf dagen van de incubatie in de bak zonder mosselen.

$\mathrm{Na}$ het meten van de hoeveelheid stof neergeslagen in de incubatiebakken kon $100 \%$ en $76 \%$ van de stof voorspelt door het model teruggevonden in respectievelijk de bak met en zonder mosselen (Figuur 3 rechts). De stabiele concentraties waargenomen in de bak met mosselen duiden op een dynamisch evenwicht tussen invoer, afvoer en sedimentatie. De dalende ZS concentratie in de bak zonder mosselen in combinatie met een te kort $(-24 \%)$ in de massabalans wijst op een intensivering van de afvoer mogelijk als gevolg van de opwerveling van eerder neergedaald sediment. Het feit dat een dergelijk proces uit blijft in de bak met mosselen houdt waarschijnlijk verband met de incorporatie van zwevend stof in pseudofeces door de mosselen.

-> Uit deze proef blijkt dat sedimentatie processen bepalend zijn voor de concentraties van zwevende stof in de incubatie bakken die daardoor sterk afhankelijk is van de hydrodynamica die daar tot stand is gebracht, vandaar het nut van actieve menging (roerders) in de incubatiebakken. 
->De mosselen zorgen voor een versterking van de sedimentatie flux en door het aanmaken van pseudofeces ook waarschijnlijk voor vergroting van de stabiliteit van het bezonken materiaal. ->In de bak zonder mosselen is de sedimentatie flux zwakker. Het incidenteel opwervelen van bezonken materiaal met minder cohesie dan pseudofeces zou het waargenomen gat (24\%) in de massabalans kunnen verklaren.

\subsection{Resultaten van de histopathologische analyses}

Het laagste percentage granulocytoma's komt voor in de To van de breukstenen en staalslakken experimenten, respectievelijk $3 \%$ en $0 \%$ (Tabel 3 ).

Ook in de Controle van het breukstenen experiment zijn er, na zes weken ( $\left.T_{6}\right)$ geen granulocytoma's aangetroffen in de 10 doorgemeten mosselen terwijl bij 20\% van de mosselen blootgesteld aan de breukstenen dit wel het geval was. De variatie tussen de 3 monsters van de incubatie was echter hoog en er werd geen significant verschil gevonden tussen de initiële waarden en de breuksteen incubatie (t-test, $\mathrm{p}=0.12)$.

In beide groepen (blootstelling en controle) van het staalslakken experiment zijn hoge percentages mosselen met granulocytoma getroffen, namelijk $13 \%$ van de aan staalslakken blootgestelde mosselen en $20 \%$ in de controle groep.

Tabel 3.-Resultaten van histopathologische analyses (granulocytoma's) uitgevoerd in mosselen aan het begin $\left(T_{0}\right)$ en zes weken na $\left(T_{6}\right)$ de incubatie met blootstellingen aan zwevende stof afkomstig uit Breukstenen en Staalslakken vergeleken met Controle groepen zonder een dergelijke blootstelling. $T_{0} *$ in het Breukstenen experiment $(16 / 11 / 2017)$ is de dag van ontvangst van de mosselen. 13 dagen later, op 29 november, startte het experiment. $\mathrm{T}_{0} * *$ in het Staalslakken experiment (18 december 2017) was 32 dagen na ontvangst van de mosselen (zie 2.2.3). De gekleurde arcering (blauw-magenta) is functie van het percentage granulocytoma's.

\begin{tabular}{|c|c|c|c|c|c|c|}
\hline \multirow{2}{*}{ Experiment } & \multirow{2}{*}{ Datum } & \multirow{2}{*}{ tijdstip } & \multirow{2}{*}{ Behandeling } & \multirow{2}{*}{$\begin{array}{c}\text { Aantal } \\
\text { mosselen }\end{array}$} & \multicolumn{2}{|c|}{ Granulocytoma's } \\
\hline & & & & & Aantal & $\%$ \\
\hline \multirow{7}{*}{ Breukstenen } & \multirow{3}{*}{$16 /$ Nov/17 } & \multirow{3}{*}{ TO* } & \multirow{3}{*}{ Initieel } & 10 & 0 & \multirow{3}{*}{3} \\
\hline & & & & 10 & 1 & \\
\hline & & & & 10 & 0 & \\
\hline & $11 / \operatorname{Jan} / 18$ & T6 & Controle (na 6 wk) & 10 & 0 & 0 \\
\hline & \multirow{3}{*}{ 11/Jan/18 } & \multirow{3}{*}{ T6 } & \multirow{3}{*}{ Breukstenen (na 6 wk) } & 10 & 4 & \multirow{3}{*}{20} \\
\hline & & & & 10 & 0 & \\
\hline & & & & 10 & 2 & \\
\hline \multirow{5}{*}{ Staalslakken } & 18/Dec/17 & TO** & Initieel & 10 & 0 & 0 \\
\hline & 29/Jan/18 & T6 & Controle (na 6 wk) & 10 & 2 & 20 \\
\hline & \multirow{3}{*}{ 29/Jan/18 } & \multirow{3}{*}{ T6 } & \multirow{3}{*}{ Staalslakken (na 6 wk) } & 10 & 1 & \multirow{3}{*}{13} \\
\hline & & & & 10 & 1 & \\
\hline & & & & 10 & 2 & \\
\hline
\end{tabular}

De mosselen gebruikt bij het staalslakken experiment werden 32 dagen in de experimentele omstandigheden gehouden bij de $T_{0}$ terwijl de acclimatisatie periode slechts 13 dagen was voor het breuksteen experiment. Door dit vertraagde begin van het staalslakken experiment (zie 2.2.3) zijn de resultaten van het breuksteen experiment en het staalslakken experiment niet direct vergelijkbaar. Bij de $T_{6}$ van het staalslakken experiment zijn de mosselen in de staalslakken behandeling en de controle behandeling 74 dagen in de experimentele opstelling geweest. Eventueel hierdoor veroorzaakte stress kan een mogelijke verklaring zijn voor de waargenomen verhoging in het percentage granulocytoma's in de controle- (20\%) bakken (Figuur 4). De conclusie over de aanwezigheid van granulocytoma's in mosselen blootgesteld aan stof van staalslakken is dat er geen verschil is met de controle. Daarbij 
dient wel te worden opgemerkt dat het experiment waarschijnlijk te lang heeft geduurd (zie granulocytoma's in controle).

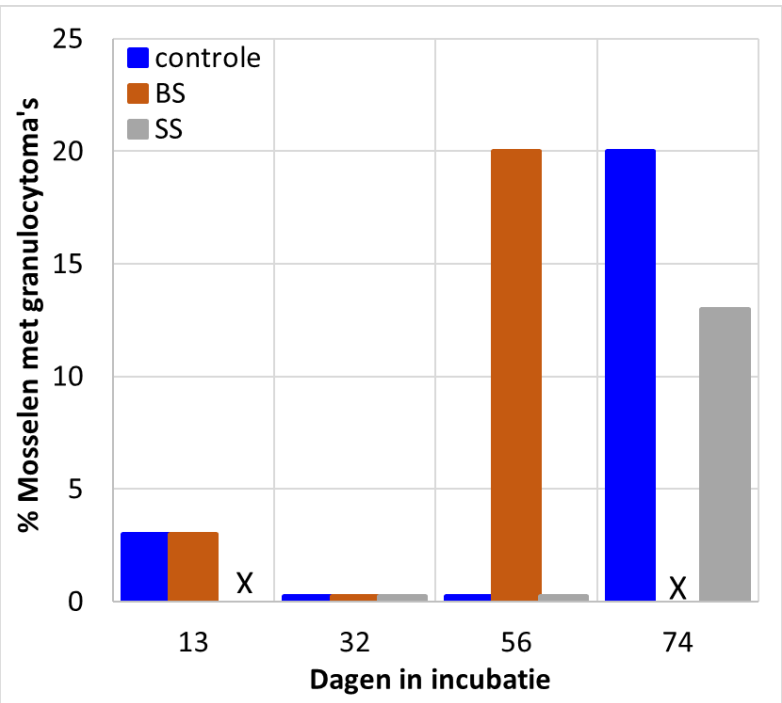

Figuur 4.-Percentage mosselen met granulocytoma's in Controle, Breukstenen (BS) en Staalslakken (SS) experiment als functie van het aantal dagen doorgebracht onder experimentele omstandigheden. Dag 13 start blootstelling aan breuksteen, dag 32 start blootstelling aan staalslakken, dag 56 eind blootstelling aan breuksteen, dag 74 eind blootstelling aan staalslakken. De $X$ staat voor en nog niet gestart experiment (SS op dag 13) dan wel voor een experiment dat is afgelopen (BB op dag 74).

->Na 13 dagen acclimatisatie in gefiltreerd zeewater met toevoeging van algenpasta als voeding en 43 dagen incubatie met bootstelling aan zwevende stof afkomstig van breuksteen zijn granulocytoma's waargenomen in $20 \%$ van de mosselen. In de controle groep ( 56 dagen in gefiltreerd zeewater met voeding) is geen verhoging t.o.v. van de initiële waarden waargenomen. Er werd echter geen significant verschil gevonden tussen de initiële waarden en de breuksteen incubatie.

-> Na 74 dagen incubatie in gefiltreerd zeewater met toevoeging van algenpasta als voeding zijn ook granulocytoma's waargenomen in $20 \%$ van de mosselen uit de controle groep wat mogelijk een gevolg is van een te lange periode doorgebracht onder die experimentele omstandigheden. Door de lange duur van het experiment zat de algenpasta tegen de grens van houdbaarheid aan.

->Er kon geen effect worden aangetoond van blootstelling aan zwevend stof afkomstig van staalslakken op de vorming van granulocytoma's bij mosselen. Na 42 dagen incubatie zijn granulocytoma's aangetroffen bij $13 \%$ van de mosselen. In de controlegroep was het aantal mosselen met granulocytoma's hoger (20\%). Mogelijk heeft de lange duur van dit experiment (72 dagen) geleid tot stress en daarmee de ontwikkeling van granulocytoma's. 


\section{$4 \quad$ Conclusies en aanbevelingen}

\subsection{Histopathologische resultaten}

De huidige resultaten wijzen niet op een mogelijk verband tussen de bloostelling aan stof uit breukstenen en de ontwikkeling van granulocytoma's bij mosselen. De zwevende stof concentraties waren in dezelfde ordegrootte als de achtergrond waarden voor de Oosterschelde. Dit is passend voor het huidige experiment dat meer gericht is op de chronische effecten van de blootstelling aan zwevende stof dan op een response op incidentele en aanzienlijke verhogingen daarin. De blootstelling aan stof uit staalslakken leidde niet tot meer granulocytoma's in de mosselen dan bij de controlegroep. Ook een langdurig verblijf onder de standaard experimentele omstandigheden (gefiltreerd water met voeding) kan ook tot de ontwikkeling van granulocytoma's leiden.

\subsection{Experimentele omstandigheden}

De gemeten fysicochemische variabelen $\left(\mathrm{pH}_{1} \mathrm{O}_{2}, \mathrm{~S} \%\right.$, $\left.\mathrm{T}^{\circ} \mathrm{C}\right)$ laten weinig afwijking zien tussen de experimentele behandelingen en de controle en de concentraties aan $\mathrm{NH}_{4}$ blijven onder kritische waarden voor mosselen. Daardoor zijn de resultaten uit de verschillende behandelingen onderling goed vergelijkbaar.

De huidige experimentele opstelling is gekenmerkt door sedimentatie in de incubatie kamers (ca 90\% van de toevoer). Een verhoging van de menging in de incubatie kamers zou blootstelling aan hogere concentraties zwevende stof mogelijk maken. De incorporatie van stof in pseudofeces door mosselen speelt mogelijk een rol in het neerslaan van sediment.

\subsection{Aanbevelingen}

Uit de huidige pilot kunnen de volgende aanbevelingen worden geformuleerd voor vervolgonderzoek:

- Gebruik van replica's bij de toepassing van de behandelingen en zo mogelijk instellen van gradiënten in zwevende stof tussen de behandelingen.

- Betere menging in de incubatiebakken om sedimentatie te beperken en daardoor de concentratie zwevend stof op peil te houden.

- Acclimatisatie periode niet langer dan 14 dagen laten duren om lang verblijf onder experimentele omstandigheden te voorkomen.

- Onderzoek doen naar de ontwikkeling van granulocytoma's in natuurlijke situatie en als functie van het verblijf in experimentele omstandigheden. 


\section{$5 \quad$ Kwaliteitsborging}

Wageningen Marine Research beschikt over een ISO 9001:2008 gecertificeerd kwaliteitsmanagementsysteem (certificaatnummer: 187378-2015-AQ-NLD-RvA). Dit certificaat is geldig tot 15 september 2018. De organisatie is gecertificeerd sinds 27 februari 2001 . De certificering is uitgevoerd door DNV Certification B.V.

Het chemisch laboratorium te IJmuiden beschikt over een NEN-EN-ISO/IEC 17025:2005 accreditatie voor testlaboratoria met nummer L097. Deze accreditatie is geldig tot 1 april 2021 en is voor het eerst verleend op 27 maart 1997; deze accreditatie is verleend door de Raad voor Accreditatie. Het chemisch laboratorium heeft hierdoor aangetoond in staat te zijn op technisch bekwame wijze valide resultaten te leveren en te werken volgens de ISO17025 norm. De scope (L097) met de geaccrediteerde analysemethoden is te vinden op de website van de Raad voor Accreditatie (www.rva.nl).

Op grond van deze accreditatie is het kwaliteitskenmerk $\mathrm{Q}$ toegekend aan de resultaten van die componenten die op de scope staan vermeld, mits aan alle kwaliteitseisen is voldaan.. Het kwaliteitskenmerk Q staat vermeld in de tabellen met de onderzoeksresultaten. Indien het kwaliteitskenmerk $Q$ niet staat vermeld is de reden hiervan vermeld.

De kwaliteit van de analysemethoden wordt op verschillende manieren gewaarborgd. De juistheid van de analysemethoden wordt regelmatig getoetst door deelname aan ringonderzoeken waaronder die georganiseerd door QUASIMEME. Indien geen ringonderzoek voorhanden is, wordt een tweede lijnscontrole uitgevoerd. Tevens wordt bij iedere meetserie een eerstelijnscontrole uitgevoerd. Naast de lijnscontroles wordende volgende algemene kwaliteitscontroles uitgevoerd:

- Blanco onderzoek.

- Terugvinding (recovery).

- Interne standaard voor borging opwerkmethode.

- Injectie standard.

- Gevoeligheid.

Bovenstaande controles staan beschreven in Wageningen Marine Research werkvoorschrift ISW 2.10.2.105

Indien gewenst kunnen gegevens met betrekking tot de prestatiekenmerken van de analysemethoden bij het chemisch laboratorium worden opgevraagd.

Indien sprake is van onbeheerste kwaliteit worden passende maatregelen genomen. 


\section{Literatuur}

Auffret, M., 1988. Histopathological changes related to chemical contamination in Mytilus edulis from field and experimental conditions. Marine Ecology Progress Series 46, 101-107.

Bignell, J.P, Stentiford, G.D, Taylor, N.G.H., Lyons, B.P. (2011) Histopathology of mussels (Mytilus sp.) from the 1 Tamar estuary, UK. Marine Environmental Research 72:25-32 10.1016/j.marenvres.2011.05.004

Blanco Garcia, A., Kamermans, P., 2015. Optimization of blue mussel (Mytilus edulis) seed culture using recirculation aquaculture systems. Aquaculture Research, 46, 977-986.

Foekema, E.M., Heuvel-Greve, van den M.J., Sonneveld, C., Hoornsman, G., Blanco Garcia, A. 2016. Uitloging en effecten van metalen uit staalslakken beoordeeld in mesocosms. IMARES Wageningen UR. Rapport nummer. C063/16

Jansen, H. M., S. Glorius, M. Tangelder en M. J. Van den Heuvel-Greve (2015) Gehaltes aan zware metalen in biota op stort- en referentielocaties in de Oosterschelde \& Westerschelde. IMARES, Rapport nummer: C079/15.

Smaal, A.C., 2015. Mogelijk verband tussen het storten van zeegrind en sterfte van mosselen op nabij gelegen percelen Hammen 62,63 en 64. IMARES, Rapport C105/15.

Sunila, I., 1984. Copper- and cadmium- induced histological changes in the mantle of Mytilus edulis L. (Bivalvia). Limnologica 15 (2), 523-527.

Widdows J. en B.L. Bayne (1971) temperature acclimation of Mytilus edulis with reference to its enery budget. J. Mar. Biol. Ass. UK. 51: 827-843.

Wijsman, J. W. M. 2016. Schelpdiersterfte, wat zijn de mogelijke oorzaken van sterfte van mosselen op de kweekpercelen? Helpdesk Mosselkweek 2016-04, Wageningen Marine Research.

Wijsman, J.W.M.; Dedert, M.; Schellekens, T.; Teal, L.R.; Kruchten, Y. van 2012. Case Study Mussels - Modeling the effect of dredging on filter-feeding bivalves. Report / IMARES Wageningen UR C123/12.

Wijsman, J. W. M., M. J. J. Kotterman en C. J. A. F. Kwadijk. 2015. Energetische stoffen en zware metalen in schelpdiervlees bij munitiestort Gat van Zierikzee. IMARES, Rapport nummer: c040/15. 


\section{Verantwoording}

Rapport C077/18

Projectnummer: 4313200003-01

Dit rapport is met grote zorgvuldigheid tot stand gekomen. De wetenschappelijke kwaliteit is intern getoetst door een collega-onderzoeker en het verantwoordelijk lid van het managementteam van Wageningen Marine Research

Akkoord:

Jeroen Wijsman

Senior onderzoeker

Handtekening:

Datum:

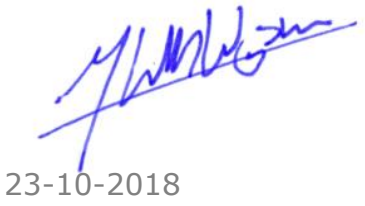

Akkoord:

Jakob Asjes

MT lid integratie

Handtekening:

Datum: 


\section{Bijlage 1 Protocol Mosselsterfte experiment}

Doel: testen van effect blootstelling aan stof van breuksteen en staalslakken op ontstaan van granulocytoma's bij mosselen.

\section{Benodigdheden:}

- Klimaatkamer op temperatuur van moment van verzamelen mosselen

- Gefiltreerd zeewater

- 130 consumptieformaat mosselen uit Waddenzee

- 9 netjes voor mosselen

- 3 cementkuipen van 30 liter

- luchtpomp voor 4 aansluitingen

- 3 ronde voorraad bakken (60 liter cementkuipen) met gefiltreerd water (controle), breuksteen of staalslakken

- 1 peristaltische pomp met 3 koppen voor toevoer gefiltreerd water (controle), water uit breuksteen bak en water uit staalslak bak

- 6 pompjes voor rondpompen water in voorraad bakken

- 2-6 tijdklokken

- Shellfish diet

- Cementkuip met ijs voor shellfish diet

- 20 liter emmer voor shellfish diet

- 1 peristaltische pomp met 1 kop voor toedienen shellfish diet

- SPM meter (C3)

- filters voor bepaling concentratie gesuspendeerd materiaal

- gekalibreerde $\mathrm{pH}$-meter

- gekalibreerde temperatuurmeter

- gekalibreerde $\mathrm{O}_{2}$-meter

- gekalibreerde saliniteitsmeter

- snelle ammonium- en nitriet-test

- Davidsons fixatief

- Ethanol

- monsterpotjes

\section{Opsteling:}

Drie cementkuipen met ieder 3 netjes. Elk netje bevat 10 mosselen. Luchttoevoer in de cementkuipen. Drie voorraad vaten met gefiltreerd zeewater (controle), breuksteen (125 g per liter) en staalslak (125 $\mathrm{g}$ per liter). Water in voorraad vaten wordt rondgepompt met twee pompjes die ieder een andere kant op pompen. Laat steeds 1 pompje aan zijn, dus 3 pompjes op 1 tijdklok en 3 pompjes op de andere tijdklok. Interval van te voren uittesten (b.v. een uur aan en een uur uit, het water moet troebel blijven). Het water in het voorraad vat wordt in 24 uur naar de cementkuip met mosselen gepompt met een peristaltische pomp. Een 20 liter emmer met beluchting geplaatst in een cementkuip gevuld met water aangesloten aan een koeling $\left(4^{\circ} \mathrm{C}\right)$ is gebruikt als voorraad voor de voedselsuspensie (Shellfish diet). Deze wordt in 24 uur naar de cementkuip met mosselen gepompt d.m.v. een peristaltische pomp. Stem het volume van de cementkuipen met mosselen af op het volume aan water en algen dat in 24 uur wordt toegevoegd.

\section{Metingen mosselen voorafgaand aan experiment:}

Bepaal het nat vlees gewicht van 10 mosselen voor berekening hoeveelheid shellfish diet. Fixeer 30 mosselen in Davidsons fixatief en later in ethanol (zie apart protocol in Bijlage 2).

\section{Toedienen shellfish diet:}

$3.6 \mathrm{ml}$ Shellfish Diet per $100 \mathrm{~g}$ of meat (WET weight) per day.

A peristaltic pump may be used to automatically dispense Shellfish Diet into the culture tank.

Dispensing feed at frequent intervals makes it possible to maintain a steady food concentration in the culture tank, avoiding both overfeeding and underfeeding. Shellfish Diet should be pumped from a reservoir housed in a refrigerator or ice-water bath. Experience has shown that the residence time of 
the feed in the tubing that delivers the feed to the culture tank is so short that this brief exposure to higher temperatures has no adverse effects on the quality of the feed.

The preferred protocol is: (1) add the desired amount of pre-diluted feed to a 5 gallon bucket. (2) Fill the bucket to 16 liters with $\mathrm{NaCl}$ water. (3) Add Reed Mariculture's buffer mix at a rate of $100 \mathrm{~g}$ per liter of feed. (4) Keep the mixture suspended with a low-shear micro-submersible pump, aeration, or magnetic stirrer. Low-shear micro-submersible pumps are available from Reed Mariculture. (5) Pump to your culture tank with a 15 liter per day peristaltic pump, or a higher-flow pump controlled by an interval cycle timer.

\section{Monitoren waterkwaliteit:}

Dagelijks monitoren van onderstaande parameters en noteren in Excel sheet op W schijf. Als waarden redelijk stabiel blijven kan frequentie naar beneden. Waterkwaliteitsmetingen: temperatuur, zoutgehalte, $\mathrm{pH}, \mathrm{O}_{2}$, TAN met grenswaarden op basis van Blanco Garcia \& Kamermans (2015). Turbiditeit d.m.v. metingen met $\mathrm{C} 3$ en watermonster over filter.

\begin{tabular}{|l|l|l|}
\hline Water kwaliteitsparameter & Range & Absolute limiet \\
\hline Temperatuur $\left({ }^{\circ} \mathrm{C}\right)$ & $16-18$ & Min 12; Max 22 \\
\hline Zoutgehalte $(\mathrm{o} / \mathrm{oo})$ & $25-30$ & Min 20; Max 34 \\
\hline Zuurstof $(\mathrm{mg} / \mathrm{l})$ & $6-8$ & Min 5; Max 10 \\
\hline pH & $7-8$ & Min 6; Max 8.5 \\
\hline TAN $(\mathrm{mg} / \mathrm{l})$ & $0-0.5$ & Min 0; Max 4 \\
\hline $\mathrm{NO}_{2}-\mathrm{N}$ & $0-0.5$ & Min 0; Max 0.5 \\
\hline $\mathrm{NO}_{3}-\mathrm{N}$ & $0-250$ & Min 0; Max 300 \\
\hline
\end{tabular}

\section{Water verversen:}

Dagelijks, na het meter van de waterkwaliteit, zoveel water verwijderen uit de tanks als er weer in 24 uur bij moet komen. 1x per week cementkuipen met mosselen helemaal leeg en schoon. Daarna weer water en algen toevoegen tot niveau van verversen. Verwijder alle dode mosselen en noteer datum en uit welke behandeling ze komen. Als er nog vlees in zit dan fixeren in Davidsons fixatief.

\section{Eindbemonstering:}

Verzamel na 6 weken alle mosselen en fixeer ze in Davidsons fixatief en later in ethanol (zie apart protocol in Bijlage 2). Stuur de monsters naar Lelystad. Van tevoren aankondigen dat de monsters komen.

Analyseer de filters voor gesuspendeerd materiaal. 


\section{Bijlage 2 Fixeren schelpdieren voor histologisch onderzoek}

\section{Werkwijze}

- Schelpdieren in vers zeewater verwateren (om zand kwijt te raken).

- Schelpdieren openen.

- Diagonale sectie van het weefsel voor histologie uitknippen met weefsel van mantel, kieuw, digestive diverticulum en gonade (zie onder).

- Leg het stukje weefsel in een embeddingcassette (Klinipath) en sluit de deksel.

- $\quad$ Fixeer de cassette in Davidson's fixatief (zie hieronder).

- Vervang na 24 uur het Davidson's fixatief door $100 \% \mathrm{EtOH}$.

Davidson's zeewater fixatief (voor histologisch onderzoek schelp- en schaaldieren):

Zeewater (gefiltreerd)

$100 \%$ ethanol (Nedalco 402.000.0020E)

Demi water

37\% formaldehyde (Merck 104003)

87\% glycerine (Merck 104094)

$100 \%$ ijsazijn (BDH 100015N)

Voeg alle ingrediënten bij elkaar in de zuurkast.

bewaar de oplossing bij kamertemperatuur.

Dit fixatief is onbeperkt houdbaar.
$1200 \mathrm{ml}$

$1140 \mathrm{ml}$

$60 \mathrm{ml}$

$800 \mathrm{ml}$

$400 \mathrm{ml}$

$\underline{360 \mathrm{ml}}$

Totaal $\quad 3960 \mathrm{ml}$ 
Wageningen Marine Research

T: $+31(0) 317480900$

E: marine-research@wur.nl

www.wur.nl/marine-research

Visitors address

- Ankerpark 271781 AG Den Helder

- Korringaweg 7, 4401 NT Yerseke

- Haringkade 1, 1976 CP IJmuiden
Wageningen Marine Research is the Netherlands research institute established to provide the scientific support that is essential for developing policies and innovation in respect of the marine environment, fishery activities, aquaculture and the maritime sector.

Wageningen University \& Research is specialised in the domain of healthy food and living environment.

\section{The Wageningen Marine Research vision:}

'To explore the potential of marine nature to improve the quality of life.'

\section{The Wageningen Marine Research mission}

- To conduct research with the aim of acquiring knowledge and offering advice on the sustainable management and use of marine and coastal areas.

- Wageningen Marine Research is an independent, leading scientific research institute.

Wageningen Marine Research is part of the international knowledge organisation Wageningen UR (University \& Research centre). Within Wageningen UR, nine specialised research institutes of Stichting Wageningen Research (a Foundation) have joined forces with Wageningen University to help answer the most important questions in the domain of healthy food and living environment. 